\title{
Investigation of Coagulation Activity of Cactus Powder in Water Treatment
}

\section{Hayelom Dargo Beyene, Tessema Derbe Hailegebrial, and Worku Batu Dirersa}

\author{
Department of Chemistry, Adigrat University, P.O. Box 50, Adigrat, Ethiopia \\ Correspondence should be addressed to Hayelom Dargo Beyene; hayeda21@gmail.com
}

Received 27 July 2016; Revised 18 October 2016; Accepted 7 November 2016

Academic Editor: Azael Fabregat

Copyright (C) 2016 Hayelom Dargo Beyene et al. This is an open access article distributed under the Creative Commons Attribution License, which permits unrestricted use, distribution, and reproduction in any medium, provided the original work is properly cited.

\begin{abstract}
This paper is focused on the comparative study of cactus powder, Alum, and their combination of physiochemical analyses of water sample such as TDS, $\mathrm{pH}$, conductivity, salinity, and turbidity using jar test. The result indicated that percentage removal of turbidity from turbid water sample increased from $23.9 \%$ to $54 \%$ and $28.46 \%$ to $58.2 \%$ as dose increased from 0.50 to $3.50 \mathrm{~g}$ for both cactus powder and Alum, respectively. Cactus powder also has a marginal effect on $\mathrm{pH}$ value $(7.33 \mathrm{at} 0.50 \mathrm{~g}, 7.49$ at $1.50 \mathrm{~g}, 7.57 \mathrm{at} 2.50 \mathrm{~g}$, and 7.57 at $3.50 \mathrm{~g}$ ) as compared to the usage of chemical coagulants (Alum). The salinity was increased from $0.4 \%$ to $0.69 \%$ and $0.39 \%$ to $0.98 \%$ as the dose of cactus powder and Alum increased from $0.50 \mathrm{~g}$ to $3.50 \mathrm{~g}$, respectively. The result revealed that cactus powder is more effective in $\mathrm{pH}$ upholding, TDS maintenance, and salinity removal than Alum, but their combination is the most effective in terms of turbidity removal, reduction of salinity, reduction of conductivity, and reduction of TDS and has a marginal effect on dissolved oxygen (DO) value. In conclusion, the combination of Alum and cactus powder is more effective for turbidity removal, salinity removal, and $\mathrm{pH}$ and conductivity upholding than either of them used individually.
\end{abstract}

\section{Introduction}

Water is an ever-present chemical substance which is very vital in all areas including agricultural, industrial, household, recreational, and environmental activities [1-3]. In nature, water exists in liquid, solid, and gaseous states, and it is a tasteless and odorless substance in its pure form [2, 4]. Water is a unique substance because it can naturally renew and clean itself by allowing pollutants to settle out through the process of sedimentation and flocculation process [5]. However, this natural process is too slow and difficult when excessive quantities of harmful contaminants are adjoined to the water [4]. This water, which is not suitable for drinking purpose, is called nonpotable water and the use of such water for drinking purpose leads to illnesses which are a major cause of death in many countries [4-6].

Contaminants such as bacteria, viruses, heavy metals, nitrates, and salt have polluted the given water resources $[1,5]$. This is due to inadequate treatment and disposal of waste from humans and livestock, industrial discharges, and overuse of limited water resources $[4,5]$. The quality of drinking water is determined in terms of physical, chemical, and biological parameters [6]. The limiting values of these parameters are recommended by the World Health Organization (WHO) $[2,3]$. As estimated by the World Health Organization, up to $80 \%$ of all diseases and sicknesses in the world are caused by inadequate sanitation and polluted water [3-7]. This estimation reveals that waterborne diseases contribute to the death of 4 million children in developing countries each year [4].

Around $75 \%$ of our body is occupied by water. Two-thirds of the earth is also covered with water [1,3-5]. Even if the earth is endowed with water resources, the availability of clean water is still doubtful $[2,5]$. Most urban communities collect water from a natural water body in the catchment, whether a stream, a river, or an underground aquifer $[5,8]$. The water collected from these sources is not of good quality for human consumption; it should undergo various water treatment processes to remove chemicals, organic substances, or organisms that could be harmful to the human health $[8,9]$. In this framework, water is treated to remove foreign impurities like suspended and colloidal particles, organic 
matter, microorganisms, and other substances that are deleterious to health $[5,7,9]$. These impurities comprise minerals, organic compounds, and gases that alter the physical, chemical, and biological characteristics of water [4].

The physical characteristics (turbidity, color, temperature, and electrical conductivity), chemical characteristics (total dissolved oxygen, $\mathrm{pH}$, and alkalinity), and biological characteristics of water are important factors that determine the acceptance of the drinking water $[5,9,10]$. The high turbidity of water is due to the presence of colloidal materials which provide adsorption sites for chemicals that may be harmful or cause undesirable taste and odors $[4,5]$. The presence of dissolved minerals, impurities, and suspended and colloidal particles in the water causes the increment of conductivity of the water $[3,5,7]$. Therefore, determining of the conductivity of a given water sample is a prediction of the acceptance of drinking water. Total dissolved solid is commonly used to indicate the concentration of dissolved minerals in a given water sample [8]. It mainly consists of carbonates, bicarbonates, chlorides, sulfates, phosphates, and nitrates of calcium, magnesium, sodium, and potassium and traces of iron and manganese [9]. The amount of coagulant that was added to the water sample is an important factor to destabilize colloidal particles in a given water sample $[5,8,10]$. For every coagulant, there exists an "optimal dosage" for specific water chemistry and composition at which the coagulation of particles is optimized [5-8].

1.1. Coagulant and the Coagulation Process. Coagulation is the process of destabilizing (reducing the charge) particles, while the coagulant is the material used to accomplish coagulation $[1,11]$. Flocculation is applied on the process of collision of particles to form a bigger size particle which is easy to be removed by a simple technique like sedimentation or filtration [12]. A coagulant is an umbrella that is used for the treatment of both surface water and industrial wastewater in the coagulation-flocculation process $[1,3,5]$. Coagulationflocculation is the most widely practical process for the production of potable water as well as for treating wastewaters $[4,5,9]$. This coagulant may be natural or chemical in nature $[3,12]$. Natural coagulants have been used domestically at household level for centuries in traditional water treatment in many rural areas $[2,6]$. These natural coagulants are added to the turbid water to remove the turbidity as depicted in Figure 1.

Most urban communities particularly in developing countries including our country, Ethiopia, collect water from a natural water body in the catchment, whether a stream, a river, or an underground aquifer which is not clean $[2,5,11]$. Currently, the need of clean water for everyday activities inspires many researchers to render the coagulation and flocculation processes more efficient [5]. Many scientists have been trying to purify and to treat polluted and turbid water using different chemical coagulants like Alum. Chemically, water is treated to adjust $\mathrm{pH}$, to remove solids, to disinfect water, to remove hardness, and to oxidize and to reduce dissolved elements by using coagulation and flocculation processes $[3,4,12]$.
There are many chemical coagulants like aluminum salts, ferric salt, and synthetic polymers that are widely used in water purification and treatment since ancient times [4, 5]. But these chemical coagulants release harmful substances to the environment which have detrimental effects on the human health $[2,4,6]$. Besides, they are ineffective in lowtemperature water, are relatively costly, produce large sludge volumes, and significantly affect $\mathrm{pH}$ value of the treated water. They also cause diseases like "Alzheimer" in human beings [2-5]. In order to reduce this controversy, nowadays, adding iron or aluminum salts to instigate sweep flocculation is the most foolproof and robust method. In line with current problems facing local communities, investigation of new possible usage of local plant materials for water treatment in rural areas is becoming the major focus. Therefore, this paper is focused on cactus plant as a natural coagulant since it is abundant in source and is of low price and is environmentally friendly. Therefore, the objectives of this study are to investigate the coagulation activity of cactus powder using jar test and UV spectroscopic method; to evaluate the dose effect of cactus powder on coagulation activities; and to compare the effectiveness of natural and chemical coagulants (Alum).

\section{Methods}

The study was conducted in the eastern zone of Tigray around $900 \mathrm{~km}$ far from Addis Ababa which is the capital city of Ethiopia. Mature healthy and fresh leaves of cactus plant were collected from Adigrat surrounding area. The collected leaves were washed with distilled water and were put in clean polyethylene plastic bags. The collected cactus leaves were dried in oven at $70-90^{\circ} \mathrm{C}$ temperature range. The dried cactus material was powdered using mortar and pestle and stored at room temperature until final analysis. Turbid water sample was obtained from Adigrat surrounding villages. The $10 \mathrm{~L}$ turbid water sample was fetched and stored in plastic containers prior to immediate experimentation.

2.1. Coagulation Activity Using Jar Test Apparatus. $500 \mathrm{~mL}$ of the turbid water samples was put into each of the 6 one-liter beakers and physicochemical parameters such as $\mathrm{pH}$, salinity, turbidity, conductivity, dissolved oxygen (DO), total dissolved solid (TDS), and chlorophyll A were measured using digital multimeter. Different doses $(0.50 \mathrm{~g}, 1.50 \mathrm{~g}, 2.50 \mathrm{~g}$, and $3.50 \mathrm{~g}$ ) of cactus powder and Alum were added to each of the 6 one-liter beakers simultaneously. The beaker was exposed in different rotating speeds, which consist of rapid mixing (100 rpm) for $1 \mathrm{~min}$ and slow mixing $(30 \mathrm{rpm})$ for $10 \mathrm{~min}$. Then, the beakers were removed from the jar test apparatus and allowed to settle for $20 \mathrm{~min}$. After settling, $20 \mathrm{~mL}$ of the sample was taken from each beaker. Finally, physicochemical parameters ( $\mathrm{pH}$, salinity, turbidity, conductivity, DO, TDS, and chlorophyll A) were measured and compared with pretreated and posttreated coagulants. Coagulation activity was calculated using the following equation [11]:

$$
\text { coagulation activity }=\frac{\mathrm{TB}-\mathrm{TS}}{\mathrm{TB}} \times 100,
$$

where TB is the turbidity of blank and TS is the turbidity of sample. 


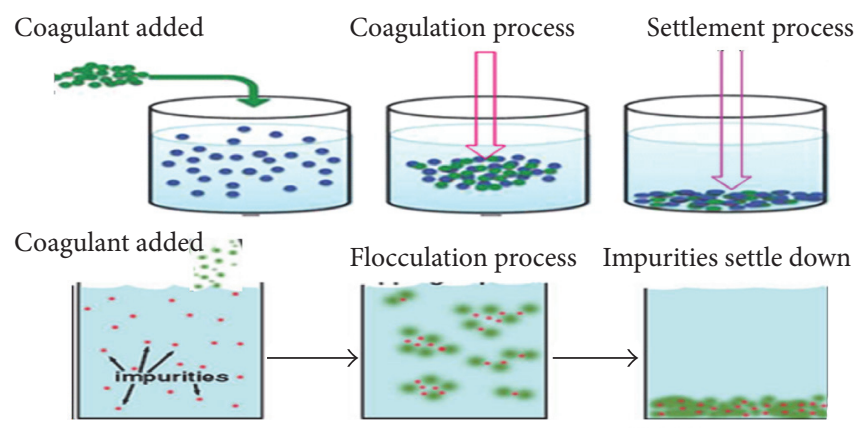

FIGURE 1: Coagulation-flocculation process in turbid water treatment.

2.2. Coagulation Activity Using UV Spectrometer. To $300 \mu \mathrm{L}$ of clay suspension water samples, cactus powder and Alum were added to a semimicroplastic cuvette and homogenized. The samples were allowed to settle for $60 \mathrm{~min}$ or more and thereafter the absorbances were measured at $500 \mathrm{~nm}$ using UV-visible spectrophotometer. The percentage of coagulation activity of cactus was calculated using the following equation [11]:

$$
\text { coagulation activity }=\frac{t_{0}-t}{t_{0}} \times 100 \text {, }
$$

where $t_{0}$ is the absorbance at $A_{500}$ measured instantly after the sample has been homogenized and $t$ is the absorbance at $A_{500}$ measured after $60 \mathrm{~min}$.

After the results were obtained and recorded, the mean, standard deviation, regression and correlation factors, and concentration were assessed using data analysis packages such as Microsoft Excel 2007 and OriginLab 8.1. All measurements were done in triplicate and the results were reported as average values \pm SD.

\section{Result and Discussion}

3.1. Coagulation Activity of Cactus Powder in Water Treatment Using Jar Test. Several chemical coagulants have been used in the treatment of polluted water such as synthetic polymer and inorganic and organic coagulants $[12,13]$. But these chemical coagulants are costly and release harmful residues to the environment [12-14]. So, in order to overcome this drawback, this study used cactus powder as a natural coagulant. In this study, the coagulation ability of cactus powder as a natural coagulant on polluted water treatment was analyzed using jar test and UV-Vis spectroscopy method. It was observed that cactus powder forms large flocs with impurities in the water sample which facilitated settling and resulted in clear supernatant formation.

In the treatment of drinking water, coagulation process is used to destabilize suspended particles and to react with dissolved organic materials in the raw water. In this study, different parameters such as conductivity, turbidity, $\mathrm{pH}$, salinity, fluoride, TDS, and DO were determined using the jar test. The results of these parameters are given in Tables 1 and 2.
3.2. Effect of Cactus Dosage on Turbidity Removal. The turbidity removal efficiency of cactus powder was determined by adding different doses of cactus powder. As shown in Figure 2, the percentage removal of turbidity from the turbid water sample was increased from $23.9 \%$ to $54 \%$ with the increment of cactus powder dosage from 0.50 to $3.50 \mathrm{~g}$. This increment in removal of turbidity is due to increment of active site of the cactus powder. Similarly, the percentage removal of turbidity from turbid water by Alum is increased from $28.46 \%$ to $58.2 \%$ as the dose of Alum increased from $0.50 \mathrm{~g}$ to 3.50 g. A similar result was reported by da Silva et al. (2016): when the dose of $\mathrm{Al}_{2}\left(\mathrm{SO}_{4}\right)_{3}(\mathrm{~mL} / \mathrm{L})$ increased from 0 to 15 by $3 \mathrm{~mL} / \mathrm{L}$ interval, the turbidity of the wastewater decreased from $1200 \mathrm{NTU}$ to $4.5 \mathrm{NTU}$ [15].

But, interestingly, the percentage removal of turbidity from turbid water by combination of Alum and cactus power is increased from $33.33 \%$ to $58.3 \%$ when the dose is increased from $0.5 \mathrm{~g}$ to $3.50 \mathrm{~g}$. The percentage removal of turbidity from turbid water by combination of Alum and cactus power is put in the order of $33.3 \%$ at $0.50 \mathrm{~g}, 38.59 \%$ at $1.50 \mathrm{~g}, 49 \%$ at $2.50 \mathrm{~g}$, and $58.3 \%$ at $3.50 \mathrm{~g}$.

Cactus powder is a natural coagulant which is effective in the reduction of water turbidity which is comparable with chitosan's work [13] and can compete with Alum in the water treatment process. Thus, the percentages of turbidity removal of Alum and cactus powder are almost equivalent. But the percentage removal of turbidity from turbid water was enhanced by combining of cactus powder and Alum as natural-chemical coagulants. This reduces the cost expense for purchasing chemical coagulant and reduces the effect of Alum on human beings and environment pollution.

3.3. Effect of Cactus Dosage on $\mathrm{pH}$ and Alkalinity of Sample. The initial $\mathrm{pH}$ value of the collected water sample was 7.81. As depicted in Figure 3, the $\mathrm{pH}$ values ranged from 7.33 to 7.57 as the cactus dosage increased from 0.50 to $3.50 \mathrm{~g}$. The $\mathrm{pH}$ value is 7.33 at $0.50 \mathrm{~g}, 7.49$ at $1.50 \mathrm{~g}, 7.57$ at $2.50 \mathrm{~g}$, and 7.57 at $3.50 \mathrm{~g}$ at different doses of cactus powder. This result implied that even though the dosages of cactus powder were substantially increased, the final $\mathrm{pH}$ values of the water sample were relatively unaffected as compared to the usage of chemical coagulants (Alum). The use of the cactus powder as a natural coagulant has no significant variation on $\mathrm{pH}$ and alkalinity of treated water. In a similar way, the $\mathrm{pH}$ value is 7.73 at $0.50 \mathrm{~g}$, 7.90 at $1.50 \mathrm{~g}, 7.67$ at $2.5 \mathrm{~g}$, and 7.77 at $3.50 \mathrm{~g}$ at different doses 


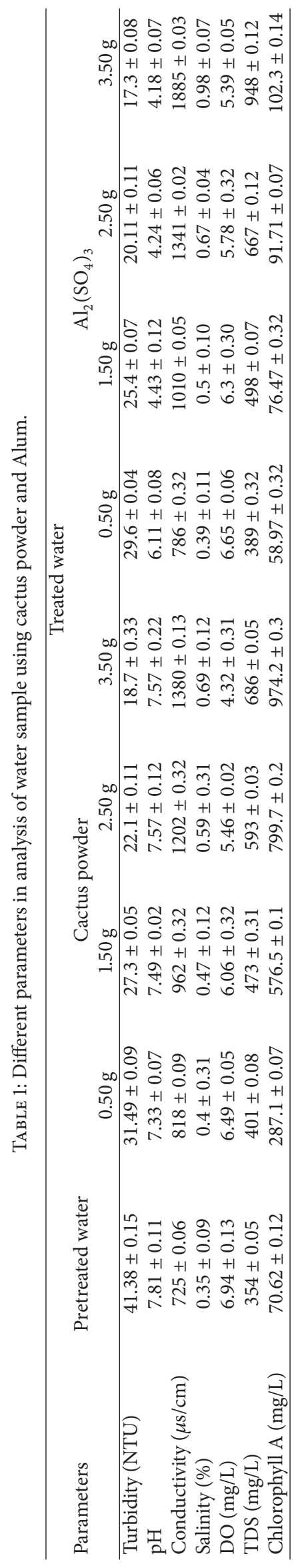


TABLE 2: Different parameters in analysis of water sample using a combination of natural-chemical coagulants.

\begin{tabular}{lccccc}
\hline Parameters & \multirow{2}{*}{ Before } & \multicolumn{3}{c}{ Proportion of cactus powder and $\mathrm{Al}_{2}\left(\mathrm{SO}_{4}\right)_{3}$} \\
& & $0.50 \mathrm{~g}$ & $1.50 \mathrm{~g}$ & $2.50 \mathrm{~g}$ & $3.50 \mathrm{~g}$ \\
\hline Turbidity (NTU) & $41.38 \pm 0.07$ & $27.6 \pm 0.05$ & $25.83 \pm 0.08$ & $21.01 \pm 0.32$ & $17.27 \pm 0.12$ \\
$\mathrm{pH}$ & $7.81 \pm 0.02$ & $7.73 \pm 0.09$ & $7.9 \pm 0.10$ & $7.67 \pm 0.02$ & $7.77 \pm 0.02$ \\
Conductivity $(\mu \mathrm{s} / \mathrm{cm})$ & $725 \pm 0.04$ & $822 \pm 0.02$ & $897 \pm 0.02$ & $1027 \pm 0.02$ & $1112 \pm 0.02$ \\
Salinity (\%) & $0.35 \pm 0.07$ & $0.37 \pm 0.05$ & $0.39 \pm 0.02$ & $0.43 \pm 0.02$ & $0.52 \pm 0.02$ \\
DO (mg/L) & $6.94 \pm 0.02$ & $6.09 \pm 0.07$ & $6.04 \pm 0.02$ & $5.86 \pm 0.02$ & $5.43 \pm 0.05$ \\
TDS (mg/L) & $354 \pm 0.02$ & $376 \pm 0.13$ & $413 \pm 0.06$ & $493 \pm 0.08$ & $557 \pm 0.04$ \\
\hline
\end{tabular}

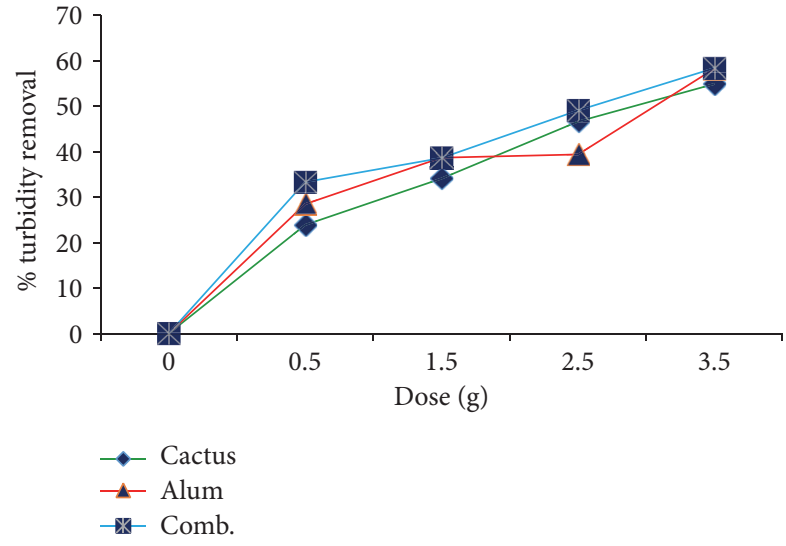

FIGURE 2: Turbidity removal capability of cactus powder and Alum at various dosages.

of cactus powder and Alum combination. A similar result was reported by da Silva et al. (2016): when the dose of $\mathrm{Al}_{2}\left(\mathrm{SO}_{4}\right)_{3}$ $(\mathrm{mL} / \mathrm{L})$ increased from 0 to 15 by $3 \mathrm{~mL} / \mathrm{L}$ interval, the $\mathrm{pH}$ of the wastewater was decreased from 7.54 to 6.79 [15].

On the other hand, when the dosages of Alum increase from $0.50 \mathrm{~g}$ to $3.50 \mathrm{~g}$, the final $\mathrm{pH}$ value of the water is significantly decreased from 6.1 to 4.18 which is acidic. This is due to the fact that Alum has the capability to react with the alkali present in the water sample. This reduces the $\mathrm{pH}$ value of the neutral water sample. This is also attributed to the fact that Alum in the water treatment process produced sulfuric acid which lowered the $\mathrm{pH}$ levels. The other reason in increment of acidity nature of the treated water sample by Alum could be due to the trivalent cation of aluminum which serves as Lewis acid [4].

In conclusion, aluminum and iron salts act as Lewis acids in solution and can consume the alkalinity of water and may demand the addition of an alkalizing agent to maintain the hydrolysis reactions $[7,9]$. This leads to wastage in economy and time to uphold the water in neutral state.

Cactus powder and the combination of cactus powder and Alum are more effective in maintaining neutrality of a water sample. They have a marginal effect on $\mathrm{pH}$ value. They maintain alkalinity concentration of cations and anions of the water sample. This does not cause corrosion problem in piping and produces less volume of sludge compared to Alum. On the other hand, aluminum ions have a highly

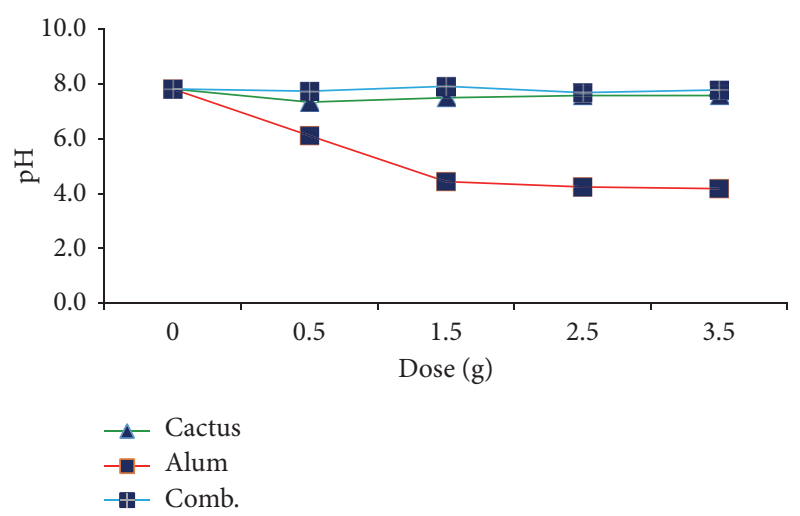

FIgURE 3: Plot of dose of coagulant against $\mathrm{pH}$ value.

positive charged species which binds to negatively charged particles to form "bridges" between them, creating larger particles that may settle or be removed by filtration [12, 14]. This increases residual aluminum concentrations in the environment. Moreover, Alum is strongly neurotoxic which causes Alzheimer's disease $[3,4,6]$. Thus, it is better to use cactus powder or a combination of cactus powder and Alum to maintain $\mathrm{pH}$ value during water treatment.

3.4. Effect of Cactus Dosage on Total Dissolved Solids (TDS). TDS is mostly used to express the concentration of dissolved minerals in a given water sample. It contains carbonates, chlorides, sulphates, phosphates, and nitrates of calcium, magnesium, sodium, and potassium $[4,8]$. It increases the conductivities of water due to the presence of those dissolved impurities [5]. The principal anions contributing to the TDS value include carbonate, bicarbonate, chloride, sulphate and nitrates, and cations: calcium, magnesium, potassium, and sodium [5]. The presence of those dissolved solids in the water sample can comprise inorganic salt and organic matter. TDS in water influence the qualities of drinking water such as taste, alkalinity, hardness, and corrosion properties [7].

As shown in Figure 4 and Table 1, the TDS values are increased from $354 \mathrm{mg} / \mathrm{L}$ to $686 \mathrm{mg} / \mathrm{L}$ as the dose of cactus increased from $0.00 \mathrm{~g}$ to $3.50 \mathrm{~g}$. In the same way, the TDS values are increased from $354 \mathrm{mg} / \mathrm{L}$ to $948 \mathrm{mg} / \mathrm{L}$ as the dose of Alum increased from $0.00 \mathrm{~g}$ to $3.50 \mathrm{~g}$. In both natural and chemical coagulants, the TDS value is increased as the dose of the coagulant increased. But cactus powder is to some extent lower in the formation of TDS than the chemical 


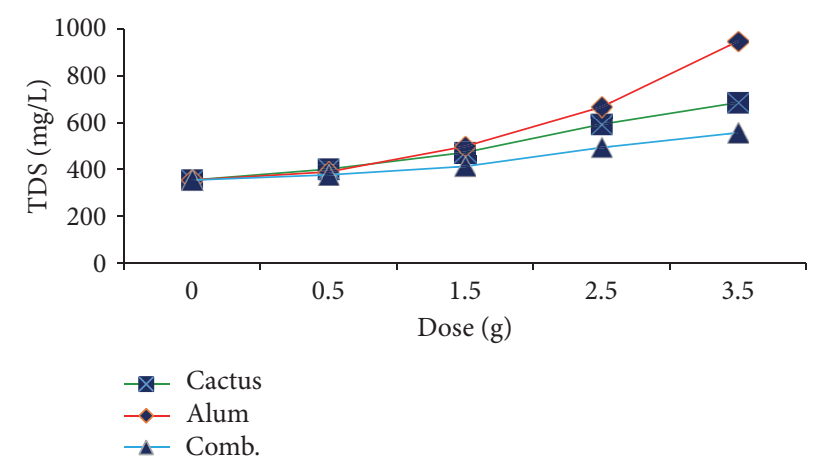

FIGURE 4: Plot of dose of coagulant against TDS value.

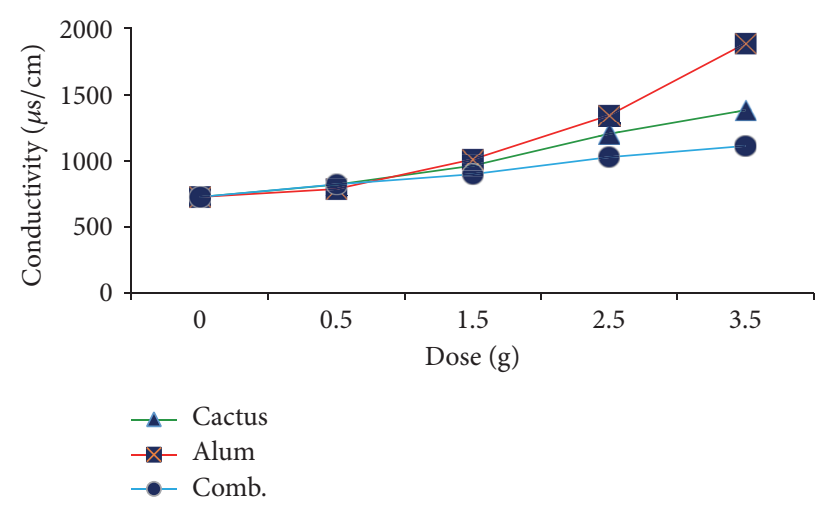

FIgURE 5: Plot of dose of coagulant against conductivity value.

coagulant (Alum). This might be due to the fact that the sludge formation in cactus powder is lower than in the Alum that rises from the basis of the coagulant and coagulation process.

On the other hand, the TDS value is $354 \mathrm{mg} / \mathrm{L}$ at $0.00 \mathrm{~g}$, $376 \mathrm{mg} / \mathrm{L}$ at $0.50 \mathrm{~g}, 413 \mathrm{mg} / \mathrm{L}$ at $1.50 \mathrm{~g}, 493 \mathrm{mg} / \mathrm{L}$ at $2.50 \mathrm{~g}$, and $557 \mathrm{mg} / \mathrm{L}$ at $3.50 \mathrm{~g}$ in the combination of cactus powder and Alum (Table 2). Thus, the combination of cactus powder and Alum is more effective in TDS upholding and sludge formation than using either of them separately; they have a synergetic effect in coagulation activity.

3.5. Effect of Cactus Dosage on Conductivity. As shown in Figure 5 and Table 1, the conductivity of the collected water sample is increased as the dose of cactus powder and Alum increased. The conductivity of the original water sample was $725 \mu \mathrm{s} / \mathrm{cm}$, but the conductivity is raised from $786 \mu \mathrm{s} / \mathrm{cm}$ to $1885 \mu \mathrm{s} / \mathrm{cm}$ as the dose of Alum increased from $0.50 \mathrm{~g}$ to $3.50 \mathrm{~g}$. In the same way, the conductivity is increased from $818 \mu \mathrm{s} / \mathrm{cm}$ to $1380 \mu \mathrm{s} / \mathrm{cm}$ as the dose of cactus powder increased from $0.50 \mathrm{~g}$ to $3.50 \mathrm{~g}$. This increment of conductivity of raw water along with the coagulant dose is due to sludge formation of the coagulants during the coagulation process $[6,9]$. Even though the conductivity of a given water sample is increased as the dose of cactus powder and Alum increased, cactus powder is relatively better than Alum in maintenance of conductivity.

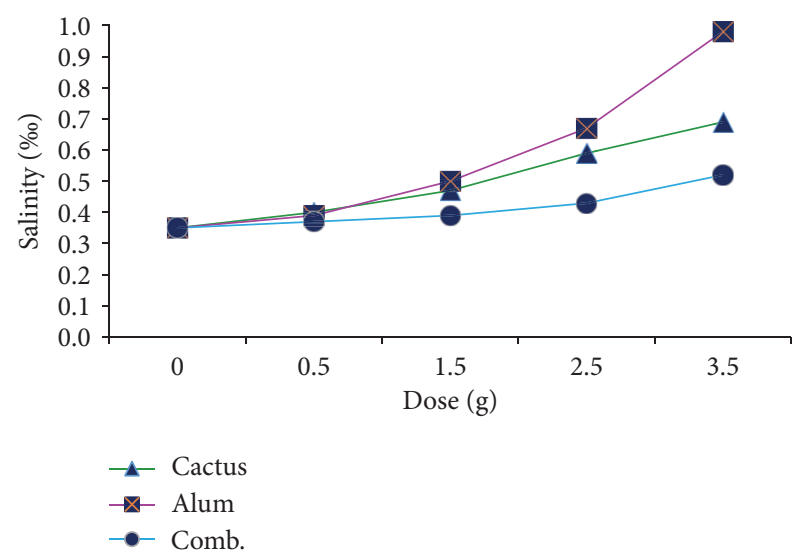

FIGURE 6: Plot of dose of coagulant against salinity value.

Interestingly, the conductivity of cactus powder and Alum combination is $725 \mu \mathrm{s} / \mathrm{cm}$ at $0.00 \mathrm{~g}, 822 \mu \mathrm{s} / \mathrm{cm}$ at $0.50 \mathrm{~g}$, $897 \mu \mathrm{s} / \mathrm{cm}$ at $1.50 \mathrm{~g}, 1027 \mu \mathrm{s} / \mathrm{cm}$ at $2.50 \mathrm{~g}$, and $1112 \mu \mathrm{s} / \mathrm{cm}$ at $3.50 \mathrm{~g}$ (Table 2). This indicates that the combination of cactus powder and Alum is more effective in maintenance of conductivity than using any of them separately.

3.6. Effect of Cactus Dosage on Salinity. As shown in Figure 6 and Table 1, the salinity of the collected water sample is increased as the dose of cactus powder and Alum increased. The salinity of the original water sample was $0.35 \%$, but the salinity is increased from $0.4 \%$ to $0.69 \%$ as the dose of cactus powder increased from $0.50 \mathrm{~g}$ to $3.50 \mathrm{~g}$. In a similar way, the salinity is increased from $0.39 \%$ to $0.98 \%$ as the dose of Alum increased from $0.50 \mathrm{~g}$ to $3.50 \mathrm{~g}$. Even though the salinity of the given water sample is increased as the dose of cactus powder and Alum increased, cactus powder is relatively better than Alum in upholding of salinity of a given water sample.

Conversely, the salinity of cactus powder and Alum combination is $0.35 \%$ at $0.00 \mathrm{~g}, 0.37 \%$ at $0.50 \mathrm{~g}, 0.39 \%$ at $1.50 \mathrm{~g}, 0.43 \%$ at $2.50 \mathrm{~g}$, and $0.52 \%$ at $3.50 \mathrm{~g}$. Thus, the combination of cactus powder and Alum is more effective in salinity removal than using any of them separately (Table 2).

3.7. Effect of Cactus Dosage on Dissolved Oxygen (DO). The initial concentration of DO in the collected water sample was $6.9 \mathrm{mg} / \mathrm{L}$. When the dose of cactus powder increased from $0.50 \mathrm{~g}$ to $3.50 \mathrm{~g}$, the concentration of DO decreased from $6.49 \mathrm{mg} / \mathrm{L}$ to $4.32 \mathrm{mg} / \mathrm{L}$. In a similar condition, when the dose of Alum increased from $0.50 \mathrm{~g}$ to $3.50 \mathrm{~g}$, the concentration of DO decreased from $6.65 \mathrm{~g} / \mathrm{L}$ to $5.39 \mathrm{mg} / \mathrm{L}$. As shown in Figure 7 , in both natural and chemical coagulants, the value of DO is decreased. This is due to the interaction of active site of coagulant with oxygen atom present in water. But once again, the combination of cactus powder and Alum does not harm the DO value of water sample as using either of them individually.

3.8. Effect of Cactus Dosage on Chlorophyll A. As depicted in Figure 8 and Table 1, chlorophyll $\mathrm{A}$ is increased from $70.62 \mathrm{mg} / \mathrm{L}$ to $974.2 \mathrm{mg} / \mathrm{L}$ as the cactus powder increased from $0.0 \mathrm{~g}$ to $3.5 \mathrm{~g}$. But it increased from $70.62 \mathrm{mg} / \mathrm{L}$ to 


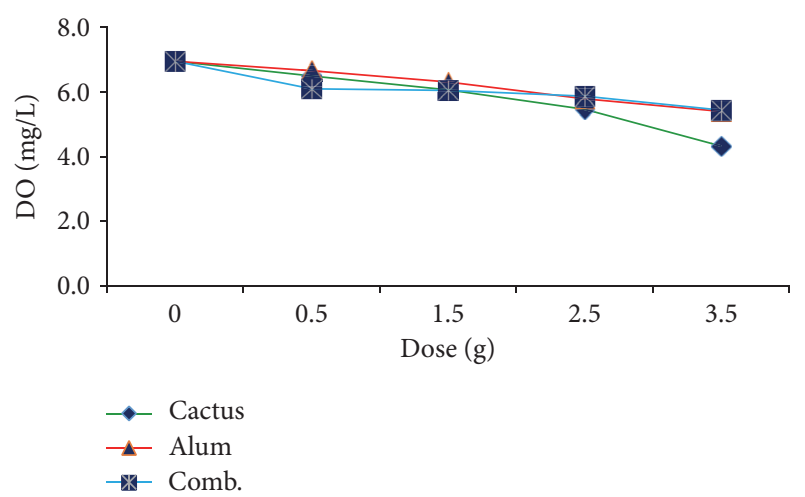

Figure 7: The plot coagulant dose against DO value.

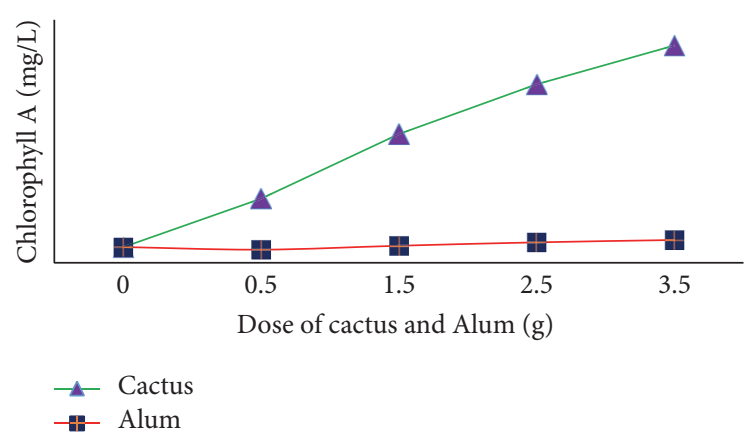

Figure 8: Plot of dose of coagulant against chlorophyll A.

$102.3 \mathrm{mg} / \mathrm{L}$ as the dose of Alum increased from $0.00 \mathrm{~g}$ to $3.50 \mathrm{~g}$. This significant increment of chlorophyll $\mathrm{A}$ in cactus powder is due to the presence of chloroplast in cactus leaves.

According to this research, the greatest obstacle to exploit cactus powder in the treatment of drinking water is color formation (high chlorophyll content of cactus powder). In order to resolve this challenge, researchers use the roasted cactus powder instead of the normal one. Besides, researchers also use white ashes from firewood; when a spoonful of white ashes is added, the color of turbid water is reduced to some extent.

3.9. Coagulation Activity of Cactus Powder Using UV Spectrometer Method. Water treatment is the process of removing undesirable chemical materials and biological contaminants from raw water [3-5]. The method leads to the destabilization and aggregation of small stable colloidal (nonsettleable) impurities, usually consisting of a combination of biological organisms such as bacteria, viruses, protozoans, and color causing particles $[1,5]$. In order to remove these contaminations from raw water, different approaches have been adopted like jar test and UV-visible spectrophotometer method. As this study has tried to confer, different physicochemical parameters were determined in the above sections using jar test. This study used UV-visible spectrophotometer to check the absorbance of water sample at different settling times $(t)$. Therefore, the coagulation activity of cactus powder was also determined using UV-visible spectrophotometer. The

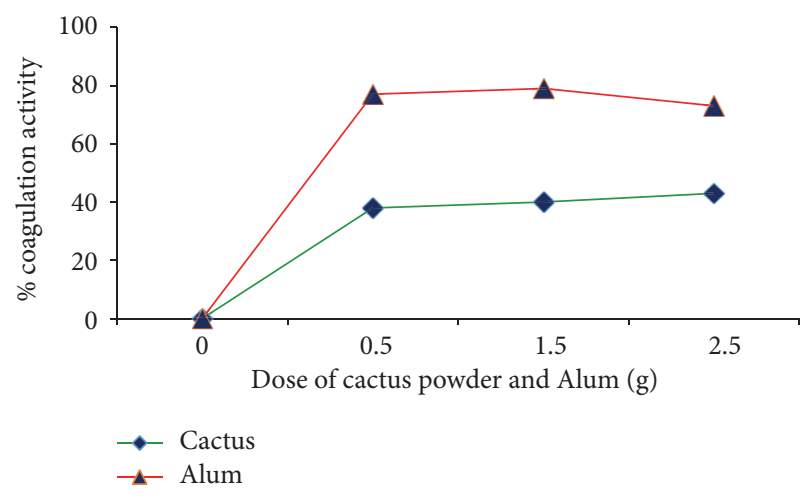

FIGURE 9: The plot of coagulant dose against coagulation efficiency.

percentage of coagulation activity of cactus powder was calculated using the following formula [11].

As shown in Figure 9, the percentage removal of turbidity from turbid water sample is increased initially with the increasing of cactus powder dose, but, after a certain dose, a decreasing trend in removal of turbidity is seen with an increment of cactus powder. This decrement of turbidity removal with increment cactus powder and Alum dose is due to equilibration of optimum dose. The performance could be explained by the fact that the optimal dose of coagulants in suspension causes a larger amount of solid to aggregate and settle. However, an overoptimal amount of coagulants would cause the aggregated particles to redisperse in the suspension and would also disturb particle settling $[2,4]$.

Cactus is used as a natural coagulant in water treatment via adsorption, neutralization, formation of hydrolysed species of positive charge in the compound, and destabilization of the particle suspension. This attraction may result from interactions of hydrogen bonding, coordination reaction, covalent reaction, and ion exchange process $[6$, $10,16]$. The main functional groups such as carboxyl and hydroxyl groups could be contributed by the protein portion of the material to bind the suspended particles by their pores [16].

The coagulation activity of cactus powder in this study was compared with previous works that have been conducted in different time and countries. This comparison helps us to check up the coagulation potential of cactus powder with other chemical and natural coagulants. The coagulation activity of Combination of Chitosan and Bentonite as Coagulant Agents in Dissolved Air Flotation conducted by Mohd Remy Rozainy et al. (2014) [16] was studied; the principal factors affecting coagulation are optimal coagulant dosage, mixing time, $\mathrm{pH}$ and mixture ratio of primary coagulant, and coagulant aid in the treatment of raw water [12,17]. The coagulation activity of cactus was also affected by the factors mentioned. Coagulation with chitosan-bentonite successfully removed the turbidity with efficiency of $97 \%$, chitosan-bentonite ratio of $30: 70$, concentration of $1000 \mathrm{mg} / \mathrm{L}(300 \mathrm{mg}: 700 \mathrm{mg}$ in 1 liter of raw water), optimal $\mathrm{pH}$ of 7.3, and 30 minutes of mixing time during flocculation, while the coagulation activity with cactus removal of turbidity from turbid water sample increased with dosage from $23.9 \%$ to $54 \%$ and 
$\mathrm{pH}$ from 7.33 to 7.57 from 0.50 to $3.50 \mathrm{~g}$ which indicates that cactus powder can serve as a natural coagulant like chitosan-bentonite [18, 19]. Enjarlis (2014) [18] studied also the application of coagulation activity on advanced oxidation process using polyaluminium chloride (PAC) and Alum as a coagulant showed the optimization of the use of coagulant and coagulation-flocculation processes with integration of ozonation; the measured parameters were TSS, $\mathrm{pH}$, odor, color, and COD. The removal percentage of chemical oxygen demand was increased from 7 to 41 as $\mathrm{pH}$ increases from 5 to 9 while the current study also showed removal percentage of total dissolved oxygen (TDO) from the raw water [19]. When we conclude this finding, cactus powder has consistency potential in turbidity removal which implies that cactus can serve as a coagulant in water treatment.

\section{Conclusion}

The turbidity removal capability of cactus powder is increased from $23.9 \%$ to $54 \%$ as cactus powder dosage increased from 0.50 to $3.50 \mathrm{~g}$. But overdosage and underdosage of cactus powder are unable to trap the desired turbidity. This implies that an optimum dose of cactus powder is required to remove the turbidity effectively. It was also proven that the cactus powder did not have a significant effect on final $\mathrm{pH}$ of turbid water, 7.33 at $0.50 \mathrm{~g}, 7.49$ at $1.50 \mathrm{~g}, 7.57$ at $2.50 \mathrm{~g}$, and 7.57 at $3.50 \mathrm{~g}$, as compared to chemical coagulants, which is significantly decreased from 6.1 to 4.18 as the dose of Alum increased from $0.50 \mathrm{~g}$ to $3.50 \mathrm{~g}$. The salinity is increased from $0.4 \%$ to $0.69 \%$ as the dose of cactus powder increased from $0.50 \mathrm{~g}$ to $3.50 \mathrm{~g}$, but it increased from $0.39 \%$ to $0.98 \%$ as the dose of Alum increased from $0.50 \mathrm{~g}$ to $3.50 \mathrm{~g}$. Even though the salinity of the given water sample is increased as the dose of cactus powder and Alum increased, cactus powder is relatively better than Alum in upholding of salinity of a given water sample.

In conclusion, the combination of Alum and cactus powder is a good coagulant for turbidity removal, salinity removal, $\mathrm{pH}$ and conductivity upholding, and other physiochemical parameters of water. Hence, it is better to use the combination of chemical coagulant Alum and natural coagulant cactus powder during water treatment. This is also effective in terms of cost and environmentally friendly and coagulation-flocculation activities.

In conclusion, the aim of this work is how to give a hint for people to get uncontaminated drinking water by costeffective means, particularly the rural people who cannot afford any water treatment chemicals, without affecting the health of their environment.

\section{Competing Interests}

The authors declare that they have no competing interests.

\section{Acknowledgments}

The researchers want to express their thanks to the College of Natural and Computational Science, Department of Chemistry, Arba Minch University, and Mekelle University for providing laboratory facilities. They extend their sincere thanks to Adigrat University, Ethiopia, for the financial supports for this study.

\section{References}

[1] P. Rajasulochana and V. Preethy, "Comparison on efficiency of various techniques in treatment of waste and sewage water-a comprehensive review," Resource-Efficient Technologies, 2016.

[2] G. Vijayaraghavan, T. Sivakumar, and A. Vimal Kumar, "Application of plant based coagulants for waste water treatment," International Journal of Advanced Research, vol. 1, pp. 88-92, 2011.

[3] M. L. Jodi, U. A. Birnin-Yauri, Y. Yahaya, and M. A. Sokoto, "The use of some plants in water purification," Research Journal of Chemistry and Materials Science, vol. 1, pp. 71-75, 2012.

[4] J. D. Peruço Theodoro, F. D. Lenz, F. R. Zara, and R. Bergamasco, "Coagulants and natural polymers: perspectives for the treatment of water," Plastic and Polymer Technology (PAPT), vol. 3, pp. 55-62, 2013.

[5] T. Kazi and A. Virupakshi, "Treatment of tannery wastewater using natural coagulants," International Journal of Innovative Research in Science, Engineering and Technology, vol. 2, no. 8, pp. 4061-4068, 2013.

[6] S. Choubey, S. K. Rajput, and K. N. Bapat, "Comparison of efficiency of some natural coagulants-bioremediation," International Journal of Emerging Technology and Advanced Engineering, vol. 2, no. 10, pp. 429-434, 2012.

[7] U. Hashim and M. Wesam Al-Mufti, "Plant seeds-potential alternative as natural coagulant to treat water for turbidity," Journal of Applied Sciences Research, vol. 9, pp. 1067-1073, 2013.

[8] A. J. Issa and O. M. Babiker, "Determination of some inorganic constituents of drinking water in zalingei town central darfur state, Sudan," Journal of Science and Technology, vol. 3, pp. 12081214, 2014.

[9] V. Napacho and S. V. Manyele, "Quality assessment of drinking water in Temeke District (part II): characterization of chemical parameters," African Journal of Environmental Science and Technology, vol. 4, pp. 775-789, 2010.

[10] B. Marina, M. T. Śćiban, and Lj. S. Jelena, "Investigation of coagulation activity of natural coagulants from seeds of different leguminose species," APTEFF, vol. 36, pp. 81-87, 2005.

[11] Y. T. Hameed, A. Idris, S. A. Hussain, and N. Abdullah, "A tannin-based agent for coagulation and flocculation of municipal wastewater: chemical composition, performance assessment compared to Polyaluminum chloride, and application in a pilot plant," Journal of Environmental Management, vol. 184, pp. 494-503, 2016.

[12] W. L. Ang, A. W. Mohammad, A. Benamor, and N. Hilal, "Chitosan as natural coagulant in hybrid coagulation-nanofiltration membrane process for water treatment," Journal of Environmental Chemical Engineering, 2016.

[13] C. Y. P. Ayekoe, D. Robert, and D. G. Lanciné, "Combination of coagulation-flocculation and heterogeneous photocatalysis for improving the removal of humic substances in real treated water from Agbô River (Ivory-Coast)," Catalysis Today, vol. 281, part 1, pp. 2-13, 2016.

[14] G. S. Simate, “The treatment of brewery wastewater for reuse by integration of coagulation/flocculation and sedimentation with carbon nanotubes 'sandwiched' in a granular filter bed," Journal of Industrial and Engineering Chemistry, vol. 21, pp. 1277-1285, 2015. 
[15] L. F. da Silva, A. D. Barbosa, H. M. de Paula, L. L. Romualdo, and L. S. Andrade, "Treatment of paint manufacturing wastewater by coagulation/electrochemical methods: proposals for disposal and/or reuse of treated water," Water Research, vol. 101, pp. 467-475, 2016.

[16] M. A. Z. Mohd Remy Rozainy, M. Hasif, Syafalny, P. Puganeshwary, and A. Afifi, "Combination of chitosan and bentonite as coagulant agents in dissolved air flotation," APCBEE Procedia, vol. 10, pp. 229-234, 2014.

[17] S. A. Manjare, S. A. Vhanalakar, and D. V. Muley, "Analysis of water quality using physico-chemical parameters tamdalge tank in kolhapur district, Maharashtra," International Journal of Advanced Biotechnology and Research, vol. 1, pp. 115-119, 2010.

[18] Enjarlis, "Application of coagulation-advanced oxidation process by $\mathrm{O}_{3} / \mathrm{GAC}$ in the fan belt wastewater treatment," $A P C B E E$ Procedia, vol. 9, pp. 145-150, 2014.

[19] I. M. Ismail, A. S. Fawzy, N. M. Abdel-Monem, M. H. Mahmoud, and M. A. El-Halwany, "Combined coagulation flocculation pre treatment unit for municipal wastewater," Journal of Advanced Research, vol. 3, no. 4, pp. 331-336, 2012. 

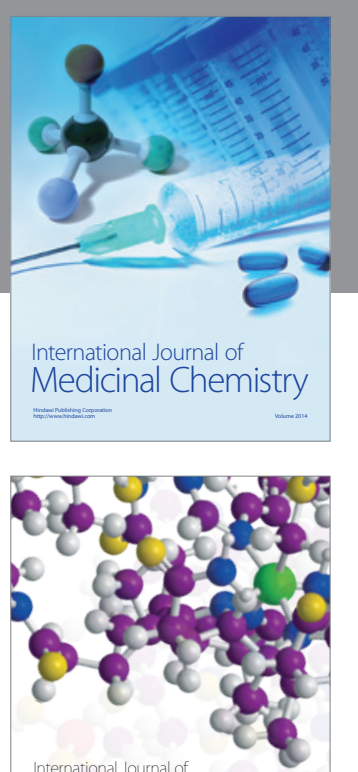

Carbohydrate Chemistry

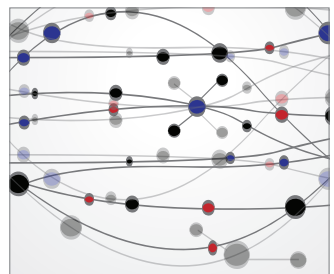

The Scientific World Journal
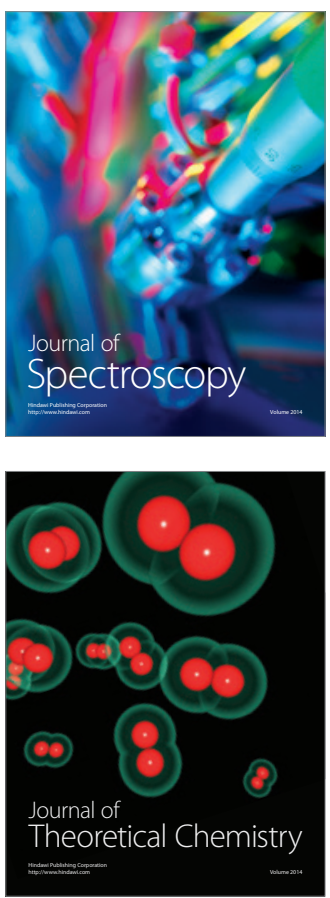
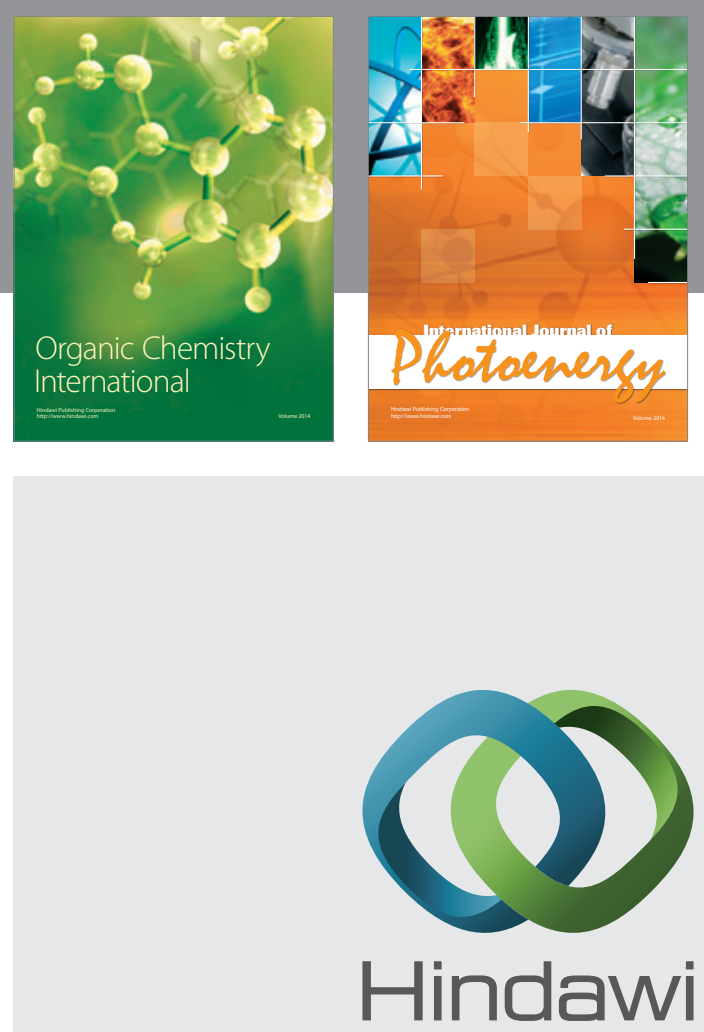

Submit your manuscripts at

http://www.hindawi.com

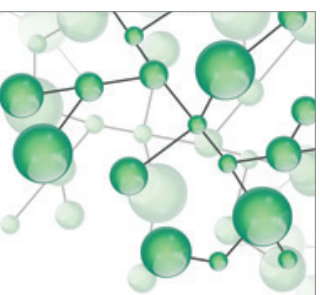

International Journal of

Inorganic Chemistry

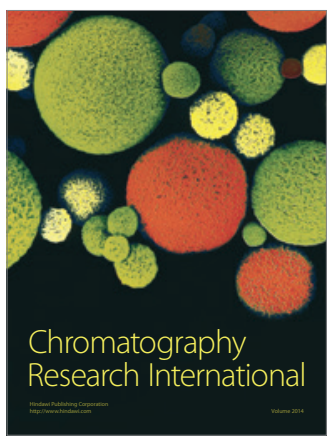

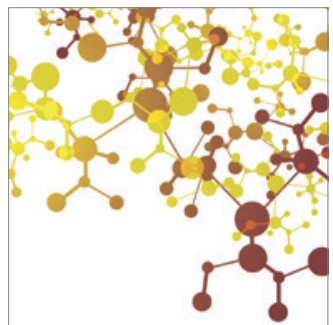

Applied Chemistry
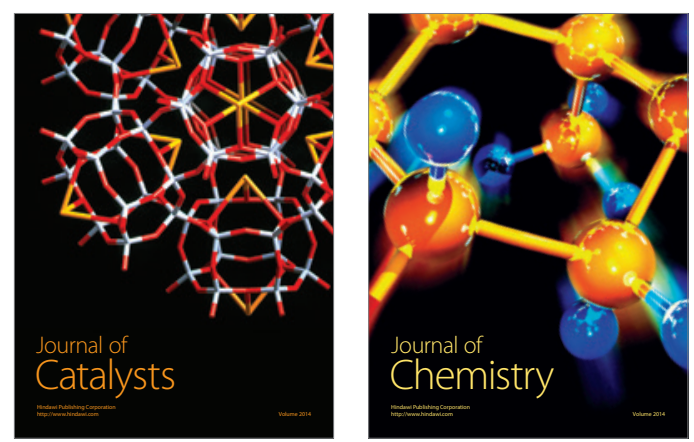
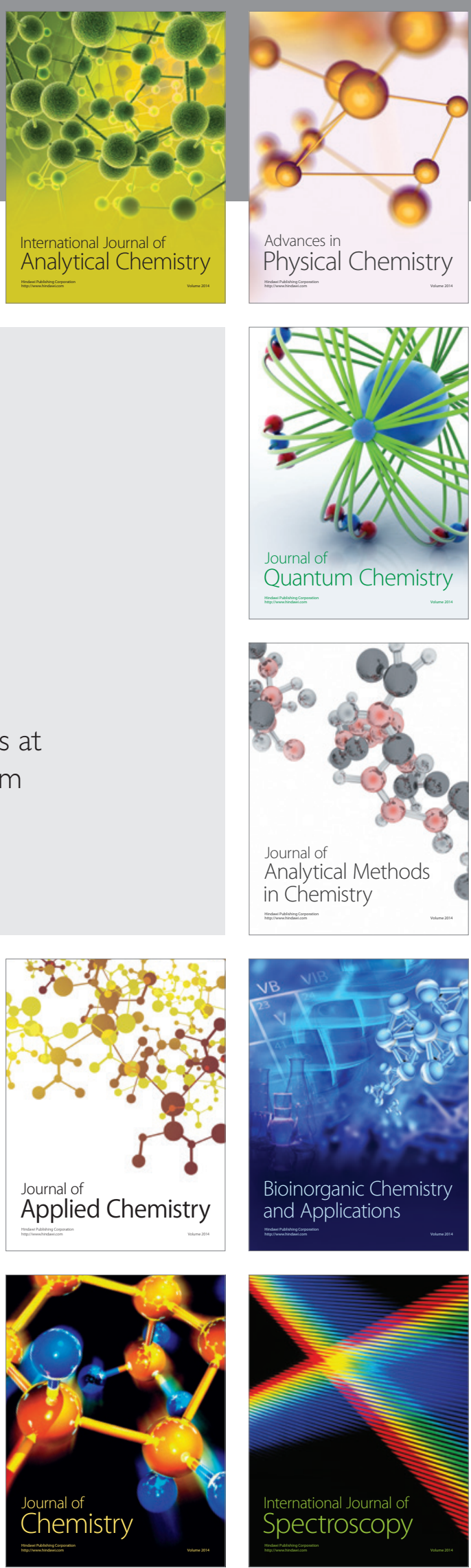